\title{
Managing Change in Banking Organisations
}

\author{
Ferenc Farkas
}

Faculty of Business and Management, University of Pecs, Hungary

\section{Abstract}

Banks and credit institutions must be managed in order to ensure that they adapt to ever-changing social needs and consumer expectations. This is an everyday lesson, but to be honest, such teachings do not say much. Practising professionals in the banking sector need something more specific and practical to be able to manage changes effectively. The findings of this paper are based on desk research and field research. Empirical evidence is provided by the application of change management models of other sectors, for the banking sector. The goal of this paper is to enlarge the relevant knowledge that is needed more than ever by the Hungarian banking sector in order to tackle the challenges it faces. And experiences show that the knowledge base available is rather limited. Since change management has never made a special attempt to resolve the organisational changes of the banking sector neither on the international nor on the domestic scene, and because references to banking organisations are few, it is also goal of this paper to show Hungarian and international mini cases and literature examples where the change management was implemented successfully and that offer lessons for other organizations.

Keywords: banking organizations, credit institutions, change management, knowledge base, Hungarian and international mini cases

JEL classification: G21

Acknowledgments: The present paper is dedicated to the 650th anniversary of the foundation of the University of Pécs, Hungary.

\section{Introduction}

The crisis culminating in the second half of the last decade has left an indelible mark on enterprises both in respect of operations and management. In retrospect, it is clear that the management of organisations was unprepared to tackle the organisational issues and requirements presented by the crisis. 150 years of Hungarian business thinking (Dobák, 2013) did not have sufficient clout at the time to enable enterprises and their management to prepare for what was looming ahead of them.

It is also a general international experience that papers and studies can become tools of prevention only to the extent of meeting their own specific goals. By definition, a crisis is a forced organisational change, and the customary response to it is proactivity. The only way organisations can achieve a more effective form of crisis management is by heightening the level of organisational responsiveness. This term appeared in the terminology of management in the 1990s. Originally, it was perceived as an ability to respond to environmental changes (Cheng and Kesner, 1988; Bartlett and Ghosal, 2002) that the role of people, in particular, the quality and adequacy of human capital, became the key driving forces behind an organisation's responsiveness.

What does organisational responsiveness imply with respect to the changes of a financial organisation? Main factors are the following: 
- The understanding of the complexities of large-scale organisational changes.

- Getting the "governors" of changes prepared.

- The expertise and knowledge of managers and their subordinates, as well as their attitude to accepting changes are of crucial importance.

- The improvement of individual competencies is a typical human resources management duty at the organisations of the financial sector.

In analysing the different aspects of organisational responsiveness, a number of specificities should be considered: knowledge depreciation has perceivably accelerated in the domestic organisations of the sector; the technologization of finance is intensifying; the tightening of the legislative environment has increased the demand for responsible working practices; the generation shift among the sector's managers and employees has accelerated, with an increase in female employees and new entrants; and employee expectations (assumptions) in respect of training and development are rapidly changing - mostly increasing - worldwide (Kaur, 2012).

Organizational responsiveness is addressed also in this paper, the goal which is to expand the relevant knowledge that is needed more than ever by the Hungarian banking sector in order to manage the challenges that it is facing. Experiences show that the available knowledge base is limited.

Change management has been a discipline for 50 years but it has never made a special attempt to resolve the organisational changes of the banking sector neither on the international nor on the domestic scene. References to banking organisations are few and far between in the otherwise ample literature, let alone comprehensive papers. For the above reasons, another goal of this paper is to show Hungarian and international mini cases and literature examples where the change management could suffice if management and employees took upon themselves the burdensome task of implementation.

The structure of the paper supports the realization of these goals. It starts with a brief description of the research methodology, followed by an introduction of theoretical issues of the change management in the banking sector (characteristics of the change management and types of changes in banks). After this, a discussion and analysis of research results is presented with the help of a special case. The conclusion contains the summary of what makes a change project successful and also limitations of the research and possible future research.

\section{Methodology}

The rich methodology of change management provides users with a multitude of procedures, models and know-how.

This paper can only offer a glimpse of how these tools are utilised in the banking business. The findings of the paper are based on desk research and field research. For the primary literature analysis the international research is used, mainly from the last decade. Empirical evidence is provided by the application of change management models used in other sectors, for the banking sector. The applicability of Jick's (1993) ten-step-model is studied with the help of the case of a Hungarian bank, based on the research of the author.

In accordance with this methodology, I first will analyse the specific features of change management in banks. 


\section{Special Traits and Types of Change Management in the Banking Sector}

The organisations of the banking sector have several special traits, which is natural as each sector differs from the others in many regards. They may differ in terms of mission, attitude to profit generation, organisational culture, applied technologies, and so on. Organisational sciences have developed numerous methodologies to explore organisational specificities, such as the approach known as contingency theories (Child, 2005), which sum up the factors affecting organisational design. Other methods, including the well-known and widely used STEEPLE-analysis (Farkas, 2013) describe the controlling specificities through exploring the external environment. This may focus on an entire sector and/or the individual organisations/enterprises of the sector. Independent (explanatory) and dependent (output) variables are customary terms in management as well, and the problem of dependency is a frequent matter of discussion.

\section{Specific Features of the Changes}

Below I examine those specificities of the banking system, which have a massive impact on organisational changes now and presumably, in the near future.

Vulnerability of the financial system as independent variable: What does this mean from the point of view of change management?

- Organisations of the banking sector are exposed to changes even if they are not the triggers or initiators of such changes individually.

- The "wind of change" may reach the sector from the outside; yet, it may be just as strong as though it had originated from within.

- The "outside", in this case, may imply the production - services - trade sectors of the economy.

- They all share the risks. During turbulent periods of change, individual organisations are unable to extricate themselves from the joint pressure to act.

- The effects of these characteristics are amplified by the globalised presence of the financial institutional system in the national economies.

- Evidently, the vulnerability of the financial system is a risk and at the same time, a strong pressure for change.

The ownership structure may impede the recognition of the trigger for organisational change:

The ownership structure of large (especially multinational) banks is complex, multiply structured and often lacks transparency. Hungarian banks are no exception after the privatisation of the banking sector. This structure has given rise to large-scale efficiency issues for some time now (Várhegyi, 1998). The revision of the structure is a change objective in itself as a macro-level change. From the aspect of nationallevel changes, concentrated professional versus dispersed ownership presents a number of dilemmas for organisational actors, including the following:

- Who are the initiators of changes from the group of owners)?

- How many channels are needed by the governing body or management representing the owner and owners' interests to become an agent of change?

- To what extent can the total separation of owners and employees ensure the formation of commitment to the change objectives?

- To what extent does the phenomenon of "Strategic decision at the centre execution at the frontiers" facilitate the formation of the commitment required by the change management models presented later in this study? 
The adjustment mechanisms of local-level (network, branch) managers and employees also have some specificity in respect of changes:

Any academic analysis of the sector's employees is inevitably distorted due to the well-known fact that financial and insurance activities are still considered to be the highest-paid branches of business. This fact alone is capable of overriding any negative personal effects of the changes in the perception of employees. Indeed, the protection of one's job and position in the sector is a strong incentive. Therefore, this specificity may well play a role in the behaviour of central corporate (higher level) management. Consequently, coercion and manipulation (Kotter and Schlesinger, 2008) tend to be more prominent during the implementation of changes in this sector than in other sectors.

Organisational changes in the banking business are governed by management. Without the determining, active role of a sufficiently "powerful guiding coalition" (Kotter, 1996), all initiatives for change are doomed from the outset. A key issue of the adjustment mechanism is the handling of resistance to change. Besides drivers of change, there are also groups and persons in a banking organisation that stubbornly resist changes. Active and passive resistance is a natural concomitant of changes, which should be handled with high expertise.

\section{Types of Changes in the Banking Sector}

The literature addressing the topic of changes offers ample advice about how to proceed in planning and implementing changes. The concepts all agree on one thing: solutions are aimed at clear state of affairs and the management of transparent situations. That notwithstanding, large-scale social and economic regime changes at the end of the 20th century and subsequently, the financialeconomic global crisis demonstrated that the set of tools available for the management of changes is insufficient, lacking any effective solutions for managing novel (or, from a different perspective, "messy") organisational situations and problems (Czinkóczi, 2013). Without a doubt, the range of concepts pondered when changes occur or when changes are being made should be broadened.

The classification that distinguishes between managed and unmanaged changes provides a sound framework for the analysis of macro and micro-level changes.

The implementation of the government's and the profession's concepts induce changes in the sector as a whole, including its organisations.

The next part of this article is focused on the analysis of managed organisational changes.

The micro-level approach to change management addresses changes initiated by member of the organisation and management. It covers intentional, purposeful organisational changes, by which the organisation intends to respond to the challenges generated by the environment and by its own internal operations. Planned organisational changes represent an intention on the part of central and local-level management and employees to improve, through the changes effected, the organisation's adaptability and alter the behaviour of individuals as intended. Nowadays the trends of differentiation and integration are simultaneously represented in organisation restructuring concepts. Under such conditions managed changes may be suitable for identifying the right orientation of organisations. Two important details of the conceptual framework of change management will need to be addressed. Firstly, the model of the equilibrium theory should be described, as it helps explore correlations between transition management and the maintenance of dynamic capabilities. Secondly, we should examine the typical attitudes to changes in various phases of the change. 


\section{Chart 1}

General Equilibrium Model

\begin{tabular}{|c|}
\hline Steady State A \\
\hline The current state, which carries the need and pressure for change \\
\hline Transition Management \\
1. Develop a vision and strategy; 2. Communicate the vision; 3. \\
Manage the execution of the strategy; 4 . Generate short-term wins \\
\hline Steady State B \\
The target state of the change, with the equilibrium restored both \\
the change, the vision developed takes hold in corporate culture \\
and operations.
\end{tabular}

Source: Based on Farkas, (2013), by Lewin, (1947)

The first question is: does the impact exerted on the organisation's participants by transformations generated by dynamic capabilities through unmanaged changes produce the same response graph as in the case of managed changes? Secondly: did resistance to the change materialise inside the organisation and how did the organisation recognise and overcome the resistance? Thirdly: did the organisation apply, during the instinctively occurring changes, the methods used to overcome resistance in the case of systematic, planned changes, including training and communication; participation and inclusion; assistance, support, negotiation and persuasion? Fundamentally, change management means managing the transition between an organisation's existing state and its future (planned) state. In the lack of pressures for change, the organisation is at rest. As soon as the triggers of change make an appearance a transformation begins, which must be constantly managed until the organisation - having incorporated the changes - returns to a state of rest. This change in equilibrium is illustrated by Chart 1.

Organisations may reach State B from State A through unmanaged changes (transitions) as well. The main difference is in controllability and the result of the expected outcome. The level of uncertainty and unpredictability depends on the mobilisation and quality of the organisation's dynamic capabilities. The methodology applied by Voszka (2013) to analyse the history of changes in state ownership in post-transition Hungary also resembles the three phases of the equilibrium model. In the author's opinion, the triad of nationalisation - privatisation nationalisation implied the vested interests and value relations of the ever-present attitude of equilibrium seeking. The desire to outdo the previous state through changes can be considered a basic goal of change management. 


\section{Discussion of Research Results}

The overview of Jick's Ten-Step-Model (1993) provides a good opportunity for analysing the case of a bank where management attempted to manage the evolution of a change that was aimed at restructuring a unit of the banking organisation:

1. Analysing the organisational need for change

Once the decision was made, management strived to provide justification for the change through several channels (e-mail, internet, meetings). Due to the nature of the situation, however, it was insufficient to be understood and accepted by everyone.

2. Creating a shared vision and common direction and

3. Separating from the past

The goal was to create a uniform communication process inside the organisation, based on standard operating procedures. With that in mind, they restructured the organisation of the unit and standardised the rules. As a result, the existing rules were either eliminated, or transformed. Management set up a separate team for the project.

4. Creating a sense of urgency

Everyone understood that it was easier to work according to uniform rules, and coworkers can offer help more easily if they understand each other's work. In addition, the clear declaration of new dependencies and responsibility levels, and especially the elimination of the previously prevailing existential uncertainty, served everyone's interest.

5. Supporting a strong leader role and

6. Lining up political sponsorship

Management intended to centralise "powers" in a single hand. To that end, management tried to ensure that the person selected to lead the change was someone respected by employees both at the professional and at the human level and clearly suitable for resolving any problems down the line. After the announcement of the decision, upper-level managers stood up for the appointee as one, making it clear that they trusted him and that they expected everyone to follow his lead and help him in his work.

7. Crafting/including an implementation plan, and

8. Developing enabling structures

Management and the new leader communicated each step of the changes throughout the project. They clarified new positions and responsibilities. Everyone was given a thoroughly specified new job description, whereby a clear picture emerged of the dependencies.

9. Communicating, involving people and being honest

Throughout the process, stakeholders and affected employees were requested for feedback at joint team building meetings, ensuring that any questions arising were analysed from different angles (e.g. evolution of personal relationships, provision of opportunities for development, etc.).

10. Reinforcing and institutionalising the change

While the change was clear, the "conclusion" of the process raised a few problems. As a result, follow-up meetings and training courses were arranged to ensure the institutionalisation and smooth functioning of the new organisational structure. 


\section{Conclusion}

As a conclusion of the analysis it first should be summarized what really works. Primary management procedures - strategy, execution, culture and structure - provide the foundation of any business:

A strategy must be clear, concise and target-oriented, and management should adhere to this principle at all times. The chosen method of growth should be carefully selected in order to avoid venturing into uncharted territories. Management should rely on the organisation's core competencies and focus on their development.

Execution means the achievement and maintenance of smooth operations. Once again, the most important factor is "how". Corporate champions are always realists. They recognise that they cannot outstrip their competitors in every aspect of their operation; therefore, they identify the processes most important for satisfying their customers' needs and then focus all their energy and resources on those particular areas to ensure that these processes are performed with maximum efficiency.

Culture must be performance-oriented. At corporate champions, everyone gives its best. These organisations create a culture that encourages outstanding individual and team performance, where not only senior and local managers, but also employees are responsible for success. This is best achieved by direct, performancebased rewards.

The organisational structure resulting from the changes should be fast and lean with an ability to respond flexibly - it should be as simple as possible.

As regards secondary practices - talent, innovation, management, fusion and partnership -, several factors are key to success, such as retaining talented employees, and recruiting new talents, adopting innovations, leaders committed to change, fusions and partnerships.

However, the management of change is not an easy task even at the local level in our case, in banking operations. Only the thirst for information, continuous learning, training and self-education can make someone the master of change management. This can be also a reason for the limitations of the research at this point: the specificities which could be used by the sector's various small or larger companies and institutions to harness the methodology and tool system of change management are not well explored and they also show a path for future research.

\section{References}

1. Bartlett, C. A., Ghosal, S. (2002),"Building Competitive advantage through people", Sloan Management Review, Vol. 43 No. 2, pp. 32-74.

2. Century Link Business (2012), "Managing Change in the Banking Industry", available at: www.slideshare.net/centuryLinkBusiness/managing-change-in-the-banking-industry (accessed September 1st 2014).

3. Cheng, J.L.C., Kesner J.F. (1988), "Responsiveness to Environmental Change: The Interactive Effects of Organisational Slack and Strategic Orientation", Academy ofManagement, No.1, pp. 165-169.

4. Child, J. (2005), "Organisation: Contemporary Principles and Practice", Blackwell, Oxford.

5. Czinkóczi, S. (2013), "A dinamikus szervezeti képességek érvényesülése irányítatlan változások révén" (Enforcement of dynamic organisational capabilities through uncontrolled changes), PhD thesis, Management and Business Administration PhD School, Faculty of Business and Economics, University of Pécs, Pécs.

6. Dobák, M. (2013), "A magyar vezetés és szervezéstudomány XX. századi fejlődése, nemzetközi és hazai társadalmi - gazdasági háttere" (20th Century Developments in Hungarian Management and Organisation Science and Its International and Domestic Socio-economic Background), in Szabó, L., Mérföldkövek és kihívások a 
menedzsmentben (Milestones and Challenges in Management), Pannon University, Veszprém, pp. 3-7.

7. Farkas, F. (2013), "A változásmenedzsment elmélete és gyakorlata" (The Theory and Practice of Change Management), Akadémiai Kiadó, Budapest.

8. Jick, T. D. (1993), "Managing Change", Cases and Concepts, McGraw-Hill, Irwin, pp. 195201.

9. Kaur, J. (2012), "Employees Perception for Training and Development: Practices in Banking", Indian Journal of Commerce \& Management Studies, Vol. 3 No. 2, pp. 85-96.

10. Kotter, J.P. (1996), "Leading change", Harvard Business School Press, Boston.

11. Kotter, J.P., Schlesinger L.A. (2008), "Choosing Strategies for Change", Harvard Business Review, Vol. 86 No. 7/8, pp. 130-139.

12. Lewin, K. (1947), "Frontiers in group dynamics-concept, method, and reality in social science: Social equilibria and social change", Human Relations, Vol. 1 No. 1, pp. 5-41.

13. Várhegyi, É. (1998), "A magyar banktulajdonosi szerkezet sajátos vonásai" (Special features of the Hungarian bank ownership structure), Közgazdasági Szemle (Economic Review), Vol. 45 No. 10, pp. 906-922.

14. Voszka, É. (2013), "Államosítás, privatizáció, államosítás (Nationalisation, privatisation, nationalisation)",Közgazdasági Szemle (Economic Review), Vol. 60 No. 12. pp. 1289-1317.

\section{About the author}

Ferenc Farkas is a full professor at the Faculty of Business and Economics at the University of Pécs. His teaching areas include change management, organizational behaviour, and leadership. His research interest focuses on non-profit management and leadership, and human resource management. He has been the team leader of Hungarian and international projects, financed by the European Union and the Hungarian government. He holds positions of Board of Directors and Board of Trustees in for-profit- and non-profit organisations. Author can be contacted at farkas@ktk.pte.hu 